existence, should also learn to live with that prospect.

When that state of affairs will come about, and what it will be like, remains anybody's guess. Despite the recent unexpected growth in the United States of the opposition to tobacco, the difficulties of carrying contentious issues such as this into law are huge. It is not just that the manufacturers are powerful corporations, but that the difficulty in striking a proper balance between public health and civil liberty are themselves substantial. But tobacco and cannabis create problems that differ only in their origin and degree. Sooner or later they will have to be dealt with together. Before then, the tobacco companies will almost certainly be shrinking under pressure from the courts.

\section{Palaeontology cleanup}

The University of Chandigarh now has a chance to shed the dubious reputation in palaeontology its has acquired.

IT is a relief, but in some ways also a surprise, that the committee of inquiry at Chandigarh appears to have found that Professor V. J. Gupta, the palaeontologist, did indeed fabricate many of the data on which his many publications have been based (see page 698). Gupta has always stoutly defended himself against criticism, but fears that his and his friends' influence would lead the inquiry in a different direction were clearly not justified. That is the good news. The other side of the coin is that the judicial inquiry into Gupta's publications has taken two years to establish what was widely accepted in 1989 . How long will it take the University of Chandigarh to decide what should happen to Gupta and his post in the geology department? And what, for that matter, should it decide?

What stands out is that the past five years have been a tragedy for the Panjab University, at which Gupta is a senior professor. The university has lost respect in the outside world, and has suffered financially. But people have also suffered. Gupta himself, despite the lifting of his suspension from his post, has not been taken seriously for the past five years and is unlikely, now, to win back his reputation. But the victims most deserving of sympathy are Gupta's less senior co-workers at Chandigarh, three of whom were also subject to the inquiry carried out by M. S. Gujral (but have been found free from taint). Their research has been interrupted just as Gupta's, but they have also had to put up with accusations of disloyalty and worse.

As a consequence, the University of Chandigarh cannot now be exclusively concerned with its own future reputation; there is also a matter of personal justice to decide. But these considerations point in the same direction, and to the conclusion that Gupta should leave the university. That is a hard thing to say of one whose whole academic life has been spent there, and who would in the ordinary course of events soon be the university dean, but the time has long since passed when the idea that substantial parts of Himalayan palaeontology might be based on salted specimens, collected from one place and described as if they had been found in another.

\section{Minority of one}

Britain seems determined to be perpetually at odds with all its fellow-members of the European Union.

Last weekend's meeting of the European Council, the governing body of the European Union (EU), was evidently disastrous. It was not the first of that kind, of course. If anything, disasters were more frequent when the EU was the European Community and when, in the early 1960 s, almost every other European Council appeared to get nowhere. But last weekend's meeting on Corfu may presage the beginning of a long spell in which Britain dissents from the opinions of all its fellow-members on all issues that happen to arise.

It is a matter of political dynamics. The British government is sustained in office by a party deeply divided on Britain's membership in the EU. A substantial fraction of government Members of Parliament wish that the EU did not exist or, given that it does, that it would go away. That same group is large enough to ensure that the government would lose any vote in the House of Commons if it chose to vote with the opposition parties against the government. So the government is sustained in power by the restraint of its internal critics on European membership. What more natural than that they should use European issues repeatedly to test the government's compliance with their wishes? There is usually at least one potential quarrel on the boil. Long before last weekend, it had become plain that the government party's dissenters would make trouble if the Prime Minister of Belgium, Mr Jean-Luc Dehaene, were to succeed M. Jacques Delors as president of the European Commission. Britain's prime minister, Mr John Major, obliged his dissenters by saying that he would not have him.

That this development will cause trouble is easily foretold, but the form the trouble will take is not. Part of Britain's objection to Dehaene is that his name had been put forward by France and Germany without consultation with Britain. But Dehaene had also earned himself in Britain the selfcontradictory reputation of being at once a "pragmatist" and a "federalist". The government could have tolerated the first, but its internal critics abhorred the second. It seems unlikely that Britain will be any more fully consulted on other candidates than in the first round.

That is a great misfortune, for the British position on the issues with which it has quarrelled with its EU partners in the past few years need not have been made to seem unreasonable. On last weekend's business, the British government would have performed a public service by pointing out that the power that has accrued during the past eight years (a measure of his competence) is anomalous. The European Commission is supposed to be the EU's executive branch, drafting legislation and looking after the money. The snag is that its members are appointed for fixed periods of time, and are awkwardly in between cabinet ministers and senior civil servants. The commission is an institution ripe for change. The British government would have done better to have said that at Corfu rather than saying it would not have Dehaene. 